\title{
The research profile of Professor Izabela Prokop. Iubilaei causa laudatio
}

\section{Augustyn Surdyk}

Adam Mickiewicz University in Poznań

SurdykMG@amu.edu.pl| 0RCID: 0000-0002-1572-1738

\begin{abstract}
The article is a tribute to Prof. Izabela Prokop, on her seventieth birthday. Its aim is to outline her academic biography, indicate numerous research interests and emphasise and appreciate her scholarly, didactic as well as organisational activity and impressive achievements.
\end{abstract}

Keywords: Izabela Prokop, iubilaei causa laudatio, tribute, research interests, academic achievements 



\section{Introduction}

In 2021 Professor Izabela Prokop, a long-time Head of the Department of Glottodidactics and Translation Studies, and Director of the Institute of Applied Linguistics ${ }^{1}$ of the Faculty of Modern Languages and Literatures at the Adam Mickiewicz University in Poznań, celebrates her seventieth birthday. On this occasion, we would like to honour the Distinguished Celebrant by presenting her person and the enormous research achievements and by dedicating this volume to her. ${ }^{2}$

\section{Academic career}

Prof. Izabela Prokop graduated from German philology (1969-1974) at the Adam Mickiewicz University in Poznań, with an excellent grade on the diploma and for the Master's thesis entitled Übersetzung als interlinguale Transformation (supervisor: Prof. Andrzej Z. Bzdęga). Then she graduated from Assistant Preparatory Studies at the Agricultural University in Poznań (1974-1975) and Postgraduate Studies in the Methodology of Foreign Language Teaching at the Institute of Applied Linguistics at the University of Warsaw (1978-1979), also working at the Agricultural University in Poznań as a German teacher (1974-1981) at the time. In 1982 she defended her doctoral dissertation entitled Deutsch-polnische Übersetzungsäquivalenz im Bereich der Dialogstrukturen (supervisor: Prof. Andrzej Z. Bzdęga), then, in 1983 she started working as an assistant professor at the Institute of German Philology AMU, and then continued

\footnotetext{
${ }^{1}$ In 1965 Prof. Ludwik Zabrocki created the Department of Applied Linguistics at the (then) Faculty of Philology of the Adam Mickiewicz University in Poznań. It was the first independent academic unit in Poland exclusively focused on research (and not educating students) within this field of study. Later the department underwent a number of transformations. After its incorporation, as a result of administrative reforms, into the Institute of Linguistics in 1970, it regained independence in 1987, as the Department of Glottodidactics. In 1991 (when the didactic profile was extended with the translation specialisation) it was transformed into the Department of Glottodidactics and Translation Studies, and finally in 2005 into the Institute of Applied Linguistics.

2 This article is an expanded and updated English version of the text entitled "Sylwetka naukowa profesor Izabeli Prokop", published in 2011 in the journal Homo Ludens (vol.3, issue 1, pp. 9-17).
} 
to work in this position at the Department of Glottodidactics and Translation Studies AMU (1992-1995). In 1995 she obtained the post-doctoral degree (habilitation) with a dissertation entitled Erotetische Sprechakte im Deutschen und im Polnischen anhand natürlicher Gespräche. In 1997-2005 she was the Head of the Department of Glottodidactics and Translation Studies, from 1999 until 2021 she was the Head of the Department of Linguistic Translation Studies (Institute of Applied Linguistics) and since 2010 she has been the Director of the Institute. In 2010, she also published a monograph entitled Aspects of pragmalinguistic analysis, the basis for the professor title application, and she obtained the title in 2013.

\section{Teaching and education of academic staff}

In addition to the research and didactic work at the Adam Mickiewicz University in Poznań, Prof. Izabela Prokop also taught at other universities. She was a lecturer at the Teachers College of Foreign Languages in Gorzów Wielkopolski (1990-1993), a tutor and a lecturer at the Teachers College of Foreign Languages in Konin (1991-1995), a professor at the Poznań Higher School of Business and Foreign Languages (2001-2004; in 2002-2004 she also worked as the rector of the School); afterwards, she was a part-time professor at the Institute of Applied Linguistics at the University of Warsaw (2005-2007), a professor at the Higher Vocational School of Computer Science in Gorzów Wielkopolski (2006-2007), and a tutor of the German section of the Teachers College of Foreign Languages in Leszno (1997-2013).

The research and teaching activity of Prof. Izabela Prokop also went beyond the borders of Poland. From October 1989 to August 1990 she was on a habilitation scholarship at the University of Christian Albrecht in Kiel. From February to July 1993 she participated in an international research group project at the Interdisciplinary Research Centre in Bielefeld, and spent the summer semester of the 2002/2003 academic year as a guest professor at the J. Gutenberg University in Mainz, at the Faculty of Philology in Germersheim.

The extensive teaching portfolio of Prof. Prokop includes such subjects as: 
1. Master's seminars in the field of German-Polish contrastive studies, pragmalinguistics and speech act theory, text linguistics, analysis of written and spoken texts, interaction and oral communication analysis, alternative methods of teaching foreign languages, shaping the autonomous attitude of pupils and students, research on national stereotypes, German-Polish intercultural communication.

2. Introduction to translation (seminar).

3. Linguistic introduction to translation (lecture).

4. Linguistic specialisation seminar for Master's students: pragmalinguistic studies with speech act theory and text linguistics.

5. Alternative methods of teaching foreign languages (lecture).

6. German-Polish contrastive grammar (lecture).

7. Descriptive Grammar of the German Language (lecture).

8. Language culture (seminar).

9. History of the German language (lecture and classes).

The students of Prof. Prokop who defended their doctoral dissertations written under her supervision include (in chronological order, according to the public dates of the doctoral defenses):

1. Dr Eliza Pieciul, 14 December 2000

2. Dr Magdalena Jurewicz, 2 April 2001

3. Dr Marcin Maciejewski, 2 April 2001

4. Dr Agnieszka Nowicka, 22 October 2002

5. Dr Michał Młodecki, 16 February 2003

6. Dr Augustyn Surdyk, 25 September 2003

7. Dr Magdalena Aleksandrzak, 25 September 2003

8. Dr Joanna Kubaszczyk, 2 October 2003

9. Dr Joanna Andrzejewska-Kwiatkowska, 27 November 2003

10. Dr Paweł Rybszleger, 12 May 2005

11. Dr Paweł Kubiak, 6 July 2006

12. Dr Małgorzata Bielicka, 4 September 2006

13. Dr Katarzyna Malesa, 12 June 2007

14. Dr Magdalena Witkowska, 2014

15. Dr Tomasz Janiak, 2020.

Seven people from those listed above, i.e. Eliza Pieciul-Karmińska (2008), Marcin Maciejewski (2010), Joanna Kubaszczyk (2013), Agnieszka Nowicka (2018), Małgorzata Bielicka (2018), Magdalena Aleksandrzak 
(2019), and Magdalena Jurewicz (2020), have already obtained the postdoctoral degree.

\section{Research interests. Theory and practice}

Research interests of Prof. Izabela Prokop include the following scientific fields:

1. German-Polish contrastive grammar.

2. Research on oral communication, including conversation analysis.

3. Intercultural communication, in particular research on the concept of national stereotype.

4. Translation studies, especially research into German-Polish translation.

5. History of the German language.

6. Teaching of foreign languages, especially the use of alternative methods.

7. Pragmalinguistics and the speech act theory.

During her 45 years of professional work, Prof. Izabela Prokop successively undertook new research problems, embedding them in her previous experience and trying to obtain a new insight into various issues through an interdisciplinary approach. Thus, for example, she noticed that in teaching of foreign languages as well as in translation studies, the linguistic symbol function has a very important role, and therefore it is necessary to include pragmalinguistics in such studies. Similarly in the field of the research methodology: the method of think-aloud protocols used in research on the translation process can be transferred to the field of glottodidactics to gain insight into e.g. the process of teachers' education, especially when it comes to shaping their research attitude and didactic metareflection.

The following part presents the moments when prof. Prokop undertook new research topics as well as the attempts to integrate them with previous research results.

Research on teaching: after graduating in 1974, Izabela Prokop, MA, started working as a German teacher at the Agricultural University 
of Poznań, teaching classes at various faculties, both day studies and extramural. A lack of German language textbooks was a serious obstacle in the implementation of the teaching tasks, which is why Ms Prokop soon decided to prepare scripts for students of the Wood Technology Faculty and the Food Technology Faculty.

Research on spoken language, translation equivalence and pragmalinguistic studies: simultaneously, Ms Prokop began preparing her doctoral dissertation entitled Translation equivalence in dialogues (Deutsch-polnische Übersetzungsäquivalenzim Bereich der Dialogstrukturen) under the guidance of Prof. Andrzej Z. Bzdęga. The doctorate was prepared in the extramural mode; only in the last months before its completion did Ms Prokop begin to work at the Institute of German Philology as a senior assistant and then an assistant professor. During this period, she intensively studied translation equivalence in various types of texts, at the same time expanding her scientific interests with further linguistic subdisciplines - pragmalinguistic studies along with speech act theory, text linguistics, and contrastive syntax. During her time at the institute, she became familiar with the principles of structural description (IC method, Glinz model, and generative transformational grammar), which later became the starting point for reflection on tertium comparationis in discourse and on the deep structure of discourse. At the same time, she started working in the international spoken language research group (project manager: Prof. Günther Richter), owing to which she was able to become thoroughly acquainted with the research methodology in the discipline (and to gather an extensive body of oral communication recordings), and as the head of the Polish branch of the project - to become acquainted with the principles of the organisation of academic research and academic international exchange.

Research on intercultural communication: during numerous trips to Germany, Dr Izabela Prokop became acquainted with publications on intercultural communication and after undergoing training in the field of sociological data collection methods in Bielefeld, she began working there at the Interdisciplinary Research Centre in an international group called The National Stereotype in Central Europe, under the guidance of Prof. Elisabeth Gülich (1992-1994). 
Research on German-Polish contrastive grammar: simultaneously, from 1985, Dr Prokop worked in the group of Prof. Ulrich Engel as a coauthor of German-Polish contrastive grammar, whose two volumes (systemic grammar) were published in Germany in 1999 and in Poland in 2000. Currently, preparations of the German-Polish communication grammar are under way.

Research on pragmalinguistics, speech act theory and conversation analysis: during the preparation of the habilitation thesis in 1989-1994, Dr Izabela Prokop focused on the issues related to the speech act theory in a contrastive approach, while using the ethnomethodological conversation analysis learned in Bielefeld. In the thesis entitled Erotetic speech acts in conversation - German-Polish contrastive study, ${ }^{3}$ the author was able to synthesise morphosyntactic contrastive studies with a pragmatic description, including conversation analysis, to capture the language in its dynamic aspect. During the preparation of the dissertation, discussions with Prof. Bzdęga, one of the reviewers, proved to be most helpful and allowed for a comprehensive, objective assessment of research tools.

Research on the history of the German language: while conducting classes on the history of the German language, Dr Izabela Prokop noticed among the students a keen interest in the intralingual translation and the analysis of old texts, which resulted in the preparation of Chrestomatia and the vocabulary of the Old High German era in cooperation with Prof. Andrzej Bzdęga.

After her habilitation in 1995 and after assuming the duties of the Head of the Department of Glottodidactics and Translation in 1996, Prof. Prokop began an intensive education of $\mathrm{PhD}$ students, bearing in mind the small number of people with a PhD degree in the department. In 1996, she started to supervise the first $\mathrm{PhD}$ students, thirteen of whom obtained a doctoral degree in the years 2000-2007. Others took doctoral examinations in the following years.

${ }^{3}$ The original title: Erotetische Sprechakte im Deutschen und im Polnischen anhand natürlicher Gespräche. Poznań: AMU Publishing House, 1995. 
Simultaneously, as the head of the unit, she aimed at optimising the teaching process in the department (introducing two-level studies, initially as an educational experiment, then as the only form of study, as well as introducing a modular-point system in 1997), in particular matching the curricula to time requirements and attempting the fullest possible implementation of the Bologna declaration. The original study plan developed by Prof. Prokop was positively assessed by the State Accreditation Commission in 2008.

Research on the teaching process: in the academic year 1999/2000, Prof. Prokop began team research on the teaching process as part of a State Committee for Scientific Research project, awarded the grant Student autonomisation and the effectiveness of language teaching at an advanced level (project manager: Prof. Weronika Wilczyńska). This research was successfully completed in 2002. The most promising results led to further research projects and to the implementation of many valuable teaching innovations. A side benefit of the project was the introduction of an innovative experiment and practical testing of some elements of alternative language teaching methods, as well as the development of the idea of Postgraduate Studies in Glottodidactics - alternative methods for teachers, which presented the latest research results in the teaching process, and for which the department received a Ministry of National Education grant in 1999.

Also in 2004, the Ministry of National Education awarded a grant to the concept of two-subject foreign language teachers' education, developed by the faculty team composed of: Prof. Teresa Siek-Piskozub, Prof. Weronika Wilczyńska, Prof. Mirosław Loba, Prof. Izabela Prokop, Prof. Jacek Witkoś, Dr Roman Pacholczyk. Between 2004 and 2007, the first cycle of this program was conducted.

Research on contrastive grammar in a communicative approach: 2000-2006 was the period of preparation of publications within the framework of the international project German-Polish communication grammar, under the guidance of Prof. Ulrich Engel (Mannheim). As part of this project, Prof. Prokop wrote 6 chapters, comprising of a total of 136 pages. 
Research on pragmalinguistics: in 2005-2010 Prof. Prokop prepared a monograph entitled Aspects of pragmalinguistic analysis, which was the basis for applying for the professor title.

Research on the spoken language: since mid-2008, Prof. Prokop has worked on the utilisation of a very extensive text corpus collected by her in 1981-1996. The file will be digitised and made publicly available. The technical check and recording inventory is in progress at the time this paper is undergoing its final revision (December 2021); the author has also been making efforts to obtain a national or an international grant for the archiving and for a further collection of the corpus. The goal is to create an empirical basis for research on spoken and written language, for the needs of German-Polish contrastive studies, for research on translation equivalence, for text structure research and pragmalinguistic studies.

Currently Prof. Prokop is working on a course-book on German grammar for Russian and Polish students, in cooperation with Prof. Olga Kostrova from the University in Samara, Russia. At the same time she is conducting research on the topic of "A beekeper's idiolect".

Other achievements in the academic work of Prof. Izabela Prokop applied in practice include:

1. Research on alternative methods: developing a concept of a summer course for students of the Teachers College of Foreign Languages in Konin (August-September 1992), using the communication method and elements of suggestopedia.

2. In the academic year 1992/1993, application of the project method in teaching at the Teachers College of Foreign Languages in Konin.

\section{Membership in academic bodies and publications}

Professor Izabela Prokop is an ordinary member of the Association of Polish Germanists, the Polish Linguistic Society, the Polish Society of Modern Languages, and the Gesellschaft für Gesprächsforschung. In 2011, at the request of the Main Board of the Games Research Association of Poland, in recognition of her work for Polish ludology, the 
association's General Assembly made Prof. Prokop an Honorary Member of the Association.

With Professor Prokop's consent, as the Head of the Department of Glottodidactics and Translation Studies, the cooperation with the association was initiated in the form of the organisation of annual academic conferences, the Poznan Chapter of the Association was established at the Institute and the Scientific Association of Applied Linguistics Students was reactivated, with its first section - the Ludological Section, which was confirmed by the consecutive Director of the Institute, Prof. Waldemar Pfeiffer. Professor Prokop agreed in 2005 to become the Honorary Chair of the Organising Committee of the first of the "Culture-Generative Function of Games" conferences, and moreover, she was a co-reviewer (together with Prof. Maryla Hopfinger-Amsterdamska from the Institute of Literary Research of the Polish Academy of Sciences, Warsaw) of the first two publications of the association, which initiated a new publication series, founded by Prof. Pfeiffer at the Institute of Applied Linguistics, entitled "Language-Culture-Communication". ${ }^{4}$ Currently Prof. Prokop is one the Members of the Academic Board of the Homo Ludens journal published by the association since 2009. In addition, since 2015 Professor Prokop has been a co-editor of the series published at the Institute together with Prof. Aldona Sopata (former Dean of the Faculty of Modern Languages and Literatures).

The academic work of Prof. Izabela Prokop consists of 3 monographs, 11 edited publications, over 50 articles, 4 conference reports, 11 reviews, 3 textbooks, 3 translations, and one other type of publication. In 2000 she was awarded the Gold Cross of Merit, in 2005 the Medal of the National Education Commission, and in 2020 - the Medal of the 100th Anniversary of Poznań University.

Finally, on behalf of the Editorial Board of this volume, we would like to express our most sincere wishes of all the best in further academic and educational work. - Ad multos annos, Professor!

${ }^{4}$ Surdyk, A. (ed.). (2007). Culture-Generative Function of Games. Game as a medium, text and ritual, volume I, series "Language-Culture-Communication" No. 1, Poznań: AMU Publishing House; Surdyk, A., Szeja, J. Z. (eds.). (2007). Culture-Generative Function of Games. Game as a medium, text and ritual, volume II, series "Language-Culture-Communication" No. 2, Poznań: AMU Publishing House. 


\section{Tabula gratulatoria}

The following current employees as well as $\mathrm{PhD}$ students of the Institute of Applied Linguistics would like to add their best wishes:

Sylwia Adamczak-Krysztofowicz

Magdalena Aleksandrzak

Camilla Badstübner-Kizik

Pascale Bali

Marta Bąkiewicz

Anna Berezowska

Małgorzata Bielicka

Katarzyna Bieniecka-Drzymała

Hanka Błaszkowska

Agnieszka Błażek

Luiza Ciepielewska-Kaczmarek

Andrzej Danielak

Kamil Długosz

Ewa Donder

Justyna Duch-Adamczyk

Elżbieta Dziurewicz

Izabella Gajewska-Głodek

Marian Glinka

Gabriela Gorąca-Sawczyk

Karolina Gortych-Michalak

Johann Görzenn

Piotr Grablunas

Milena Hadryan

Paweł Hostyński

Marta Janachowska-Budych

Barbara Jańczak

Ewa Jarmołowicz-Nowikow

Magdalena Jaszczyk-Grzyb

Magdalena Jurewicz

Karolina Kaczmarek

Sara Kähkölä
Dorota Kalecińska

Victoria Kamasa

Eliza Karmińska

Maciej Karpiński

Joanna Kic-Drgas

Katarzyna Klessa

Martyna Kokotkiewicz

Małgorzata Komorowska

Paweł Kornatowski

Graham Knox-Crawford

Monika Kowalonek-Janczarek

Katarzyna Kozińska

Lucyna Krenz-Brzozowska

Dorota Krystosiak

Joanna Kubaszczyk

Paweł Kubiak

Kwiryna Kuźmar

Marcin Lewandowski

Daniel Łubiński

Szymon Machowski

Mateusz Ławniczak

Marcin Maciejewski

Anna Marko

Aleksandra Matulewska

Marta Mazurek

Marcin Michalski

Aleksandra Muga-Bartkowiak

Jowita Niewulis-Grablunas

Joanna Nowak-Michalska

Agnieszka Nowicka

Izabela Orchowska 
Dorota Owczarek

Kiriakos Papoulidis

Waldemar Pfeiffer

Elżbieta Piasecka

Anna Pieczyńska-Sulik

Kinga Piotrowiak-Junkiert

Agnieszka Poźlewicz

Jakub Przybył

Aleksandra Przysiecka

Aleksandra Putowska

Paweł Rybszleger

Alicja Sakaguchi

Christoph Schatte

Czesława Schatte

Barbara Skowronek
Aldona Sopata

Joachim Stephan

Augustyn Surdyk

Anna Szczepaniak-Kozak

Kamil Trąba

Paula Trzaskawka

Artur Urbaniak

Elwira Wilczyńska

Danuta Wiśniewska

Magdalena Wiśniewska

Stephan Wolting

Joanna Woźniak

Esther Zarraua Isasi-Isasmenti

Marta Zawacka-Najgeburska

Nadja Zuzok

\begin{abstract}
Augustyn Surdyk, PhD - English philologist, applied linguist, glottodidactic, ludologist, assistant professor in the Department of Intercultural Communication and Ludological Studies, Institute of Applied Linguistics, the Faculty of Modern Languages and Literatures, Adam Mickiewicz University in Poznań. Founder and head of the Centre for Ludological Studies IAL (2009-2019). Member and cofounder of Games Research Association of Poland, member of the Managing Board (Treasurer); President of Poznań GRAP Centre at IAL AMU, head of the organising committee of the cycle of international academic conferences entitled "CultureGenerative Function of Games", founding editor and editor-in-chief of the "Homo Ludens" journal.
\end{abstract}

\title{
Sylwetka naukowa profesor Izabeli Prokop. Iubilaei causa laudatio
}

Abstract: Artykut stanowi wyraz uznania dla prof. Izabeli Prokop z okazji jubileuszu siedemdziesiątych urodzin. Jego celem jest nakreślenie naukowej biografii jubilatki, wskazanie licznych zainteresowań badawczych, podkreślenie i docenienie aktywności w sferach naukowej, dydaktycznej i organizacyjnej, jak również imponujących osiągnięć.

Stowa kluczowe: Izabela Prokop, iubilaei causa laudatio, artykut jubileuszowy, zainteresowania naukowe, osiągnięcia naukowe 
